Volume 7 Issue 2, June 2020

Nationally Accredited Journal,

Decree No. B/4130/E5/E5.2.1/2019

\title{
Roles And Responsibilities Of Notary Deed In Limited Liability Company (PT) In Order To Improve The Economy Of Indonesia Especially In Blora
}

\author{
Christian Bagoes Prasetyo ${ }^{1}$, Aryani Witasari ${ }^{2}$, Akhmad Khisni ${ }^{3}$
}

\begin{abstract}
The purpose of this study was to: 1) Knowing and To study Role in Making of Notary Deed of Limited Liability Company in order to boost the economy in Indonesia. 2) Knowing and To study Roles and Responsibilities of the Notary in order to boost the economy in Indonesia 3) Know and To study barriers of Notaries in Deed Limited Liability Company in order to boost the economy in Indonesia. The method used sociological juridical research specification employed is normative, data retrieval methods used primary data and secondary data, and then analyzed with descriptive analytical method.

Based on the results of data analysis summarized that: 1) The role of the Notary of the government in economic development in Indonesia give legal certainty and legal protection in the field of engagement and agreement 2) the presence of a notary becomes the spirit of the country's economic and social life and economic growth of Indonesian society. 3) barriers of notaries are facing is the technical suppose that the shareholders can not show passbooks are used as evidence of the capital and system of AHU Online / Legal Administration System $(\mathrm{SABH})$ are always changing and error system.

Keywords: Notary Role; Responsibilities Notary Deed of Limited Liability Company; Economy of Indonesia; Blora.
\end{abstract}

\section{Introduction}

Humans as a legal subject that live in groups within a particular community in a particular region is called society, in life based on their interactions with one another. Society according to nature can not live alone, but their mutual contact. Such interaction is to involve two parties, in the sense that each party wishes to obtain benefits and advantages. It spring both sides are bound to do so thus the entire group of course the existence of the bonds that arise will require rules. For if there are no clear rules, will give rise to a conflict of interest that could result in a deterioration in group life. The tendency of a settlement of a lawsuit related to the cooperation contract,

Notary is a public official authorized to make an authentic deed and have more authority as referred to in this Act or under any other laws. ${ }^{4}$

One of the duties and authority of the notary is to provide legal counseling in connection with a deed one of which is incorporated Limited Liability Company deed.

The word "corporation" in the Indonesian language has two (2) terms, namely:

- Onderneming, which means a legal form (rechtsvorm) of something companies such as Limited Liability Company, Firm, Guild (CV)

So if say ondermeming, then what is meant is pointed at their legal form and this can take the form of two kinds: Legal or Not Legal

- Bedrijf, Problem entity such as techniques for the production of home industrial / household or home-based industry, Njijeverheid (craft or a special skill), Fabriek

\footnotetext{
${ }^{1}$ Student Master of Notary Program, Faculty of Law, Sultan Agung Islamic University, Semarang, email: tiobagoes58@gmail.com

${ }^{2}$ Lecturer, Faculty of Law, Sultan Agung Islamic University, Semarang

${ }^{3}$ Lecturer, Faculty of Law, Sultan Agung Islamic University, Semarang

${ }^{4}$ Act No. 30 of 2004 Notary
} 
(factory).$^{5}$

Notary profession to economic growth in Indonesia is very instrumental, as evidenced by the mushrooming growth of banking, macro and micro Enterprises to remote regions. It proves notary profession as an authentic deed officials can not be ignored. That is the role of notaries in Indonesia, its existence is must that every time the legal certainty needed to help the economy spirit continues to run in the field of private or public administration.

Based on the description set forth above indicate the reason for the importance of notary profession to provide legal certainty in the field of engagement and agreement it needs the services of a notary as a deed official authentic can not be ignored, the authors are interested in doing further research to be formulated in the form of research with the title "Roles and Responsibilities of Notary Deed In The Limited Liability Company to Improve the Economy Of Indonesia Especially in Blora"

\section{Method approach}

Metode approach used in this study mainly is socio-juridical approach. Which studied on The Deed of Limited Liability Company to Improve the Economy of Indonesia Especially in Blora.

\section{Results And Discussion}

\subsection{Roles And Responsibilities In Making of Notary Deed of Limited Liability Company to Improve The Economic of Indonesia Especially in Blora.}

During the Industrial Revolution 4.0's and 2020 is expected to be the industrial revolution 5.0 everything required for a quicker, faster side required efficiency appropriate to produce a breakthrough or innovation that simplify and perceived benefits but still have legal certainty. One of them was there assigned and responsibilities of the Notary. Essential Duties and Role of a Public Notary can be said to come from Article 1867, 1868 and 1870 of the Civil Code, which is located in Book IV of the Verification and expiry date, which reads as follows:

Article 1867 : Proof by writing done with the authentic writings or by writing under his hand. Article 1868 : An authentic deed is a deed in the form prescribed by law, made by or in the presence of public servants in power to it in a place where the deed made.

Article 1870 : An authentic act provides between the parties and their heirs or people who have the right of them, a perfect evidence about what was contained inside.

It can be concluded role of the notary is a right hand of government mandated by the Acts which granted the authority to create and validate an authentic deed.

Rule of Notary then transposed to the manuscript Law of the Republic of Indonesia through Act No. 30 of 2004 concerning Notary, as amended by Act No. 2 of 2014 (hereinafter both this law called Act of Notary. Responsibility Notaries are as following in accordance with Article 15 paragraph (1) of Law Notary

Notary authorized to make the deed authenticity of all deeds, agreements, and determination required by legislation and / or desired by the stakeholders to be stated in the Deed authentic, guaranteeing the creation date of the Deed, save deed, giving grosse, copy and quote Deed all of it along the Deed of making it not also be assigned or excluded to other officials or any other person specified by law.

So we can conclude Roles and Responsibilities of the Notary is officials appointed by the Act to act as a public official of a Notary main authority is to make authentic act which has the strength of evidence is perfectly alias has the highest degree of evidence of the posts which

\footnotetext{
${ }^{5}$ R. Rochmat Soemito, Himpunan Kuliah-kuliah Pengantar I/mu Ekonomi, Bandung: PT Eresco, 1966, mold-7, p. 37-38
} 
Volume 7 Issue 2, June 2020

Nationally Accredited Journal,

Decree No. B/4130/E5/E5.2.1/2019

have the force of law.The country's economy will not run if the rule of law and administration of private biding assigned to the notary stopped in one day. Business transactions they will not run.

\subsection{Notary Products on Limited Liability Company in the form of Certificates in Order to Improve the Economy of Indonesia, Especially in Blora}

The role of the notary is a public official that is to say as the hands of the representative government to boost the economy if there is no participation of notaries at enhancing the economy of Indonesia, the Indonesian economy could not move forward because of all those associated with the business entity permission or establishment must be through a notary for stage notary to give legal certainty in the field of engagement and agreement.

For example, through product deed of Limited Liability Company business. The country's economy will be crippled if the rule of law in the field of administration of private and assigned to the notary stopped in one day. Their transactions are not running, the economy will be crippled. Legal certainty into the spirit of the economy, particularly with respect to the owners and users of big capital (macroeconomic). The complexity of the work and problems faced by owners and capital use higher, because the risks they face are also getting bigger and thus require legal certainty of the presence of (Product) created an authentic deed notarized. ${ }^{6}$ Through the role of the notary enterprises obtain legal certainty and a clear legal protection, because it could be feared at this time when the venture capital base when used for terrorist funding, money laundry. Thus, in the manufacture of a Limited Liability Company is not everyone can create a Limited Liability Company, if it is his intention to business / business must have not only the capital but many so many releason releason means not only a lot of reasons but not a lot of results.

\subsection{The Obstacles in the Making of Notary Deed of Limited Liability Company in order to Improve the Economy of Indonesia.}

In carrying role of the Notary meaning as arms length of government, which could boost the economy in Indonesia in the form of deed of business of the Limited Liability Company does not escape from the barriers notary to be faced in the field by using a sociological approach interviews with Notary and PPAT Elizabeth Estiningsih SH (Senior Notary in Blora) and at the Notary Office Slamet Mulyono, SH, M.Kn.

- The shareholders did not deign to show passbooks which serve as proof as proof of their capital - each form of legalized copy of the account.

The solution: Barriers faced by Notaries are shareholders who do not want to show passbooks are used as evidence as proof of the capital - each shareholder will be used as equity in the solution is to be fixed is shown presented to the notary and legalized objectives sought to shareholders to request a copy / copy of the passbook shareholders that have been certified by the relevant bank that will be set forth in the deed equity limited liability company ie the shareholders by having a copy / photocopy of passbook that has been certified to feel totally responsible,legal certainty if the shareholders of its intention to business / business must have not only the capital but many so many releason releason means not only the only way to include a copy of the account books that have legalized so that the PT founding documents are documents which are actually discount certainty this document is not legal means of fictitious documents, but a legal

${ }^{6}$ Widhi Handoko, Dominasi Negara Terhadap Profesi Notaris, Bogor, PT Roda Publika Kreasi, 2019, p. 36 


\section{document. $^{7}$}

- The Ministry of Justice and Human Rights in the AHU system verifier Online / Legal Administration System (SABH). The verifier hamper their efforts to make the body speed: When the first list of messages can name only the name, it must include its capital base; The time duration is too long to for days; The deed of establishment if it does not fit then it can not remove

The solution: a verifier in the AHU Systems Online / Legal Administration System (SABH) should be used by the system not by the person in order to speed make more effective business entity. If it was stuck to Jakarta directly as if inscribed too long. ${ }^{8}$

\section{Closing}

\subsection{Conclusion}

Based on the research results can be concluded shall have the following:

As public officials in the field of law, notaries are involved directly or indirectly in mobility in the economy and society. The presence of a notary becomes the spirit of the country's economic and social life and economic growth of Indonesian society. The role of the Notary in deed Company Limited in order to boost the economy in Indonesia, especially in the presence of a notary public was instrumental Blora increasingly important for the Indonesian people today are growing. Indonesian society require the services of a notary to make an authentic deed. It is concerning aspects of politics, economics. social, cultural, defense and security, particularly the largest share in the economic field. Which indisputable fact often economic growth with mushrooming growth in banking, macroeconomics, microeconomics to remote villages. It requires a notary as the official authentic Akta maker negligible. This means that the role and responsibilities of a notary public for the state, its existence is a requirement that every minute it takes the state in the field of private law and public administration. In the case particularly with regard to legal certainty and the protection of engagement and agreement law field.

\subsection{Suggestion}

The country's economy will not run if the rule of law and administration of private biding assigned to the notary stopped in one day. Business transactions they will not run. So do not let the role and responsibility of the notary in Indonesia stopped in a single day with regard to legal certainty in the field of engagement and agreement for the sake of increase Indonesia's economic growth, especially in Blora.

\section{References}

[1] Act No. 30 of 2004 concerning Notary

[2] Act No. 2 of 2004 concerning amendments to the Notary Act No. 30 OF 2004

[3] Act No. 7 of 2014 on the Code of Commerce - Civil Code

[4] Act No. 30 of 2004 Notary

[5] R. Rochmat Soemito, Himpunan Kuliah-kuliah Pengantar Ilmu Ekonomi, Bandung: PT Eresco, 1966

[6] Widhi Handoko, Dominasi Negara Terhadap Profesi Notaris, Bogor, PT Roda Publika Creations, 2019

\footnotetext{
${ }^{7}$ Interview with Notary and PPAT Slamet Mulyono, SH, M.Kn, at 15:10 dated 10 September 2019

${ }^{8}$ Interview with Notary and Notary and PPAT Elizabeth Estiningsih SH, 07.30 dated December 11, 2019
} 